\title{
The Expulsion of Germans from the Chapter of Zagreb in 1458
}

In 1458, seven canons of the Chapter of Zagreb were expelled by Bishop Demetrius Cupor and his supporters. In their protest before the pope, they claimed that the only reason for that was because they were Germans. Upon examining their careers and the current political situation within the Kingdom of Hungary, it becomes clear that, although an anti-German and generally anti-foreigner sentiment was present in the country (which is apparent in the laws passed by King Matthias), the real reasons for their expulsion were political. Bishop Demetrius had spent more than a decade fighting for the bishopric against his rivals, who were protected by the Counts of Celje, the then patrons of the Diocese of Zagreb. Most of the expelled canons had been given their offices by the said family, and some of them maintained close relations with Emperor Frederick III. The fact that most of the expelled canons returned to the chapter soon after their expulsion further indicates its political background. Those who returned once again became esteemed and trusted members of the chapter. Those who did not return - three out of seven - were all in the emperor's service, and the chapter took special steps to prevent them from reclaiming their offices.

Keywords: Middle Ages, Church history, Germans, Diocese of Zagreb, ethnic intolerance

The expulsion of German canons from the cathedral chapter of Zagreb was previously researched very little, as the only documents mentioning the event were kept in the Vatican Secret Archive. As such, they were virtually unknown to researchers before Andrija Lukinović discovered and published them in the 2000s. He briefly mentioned the event in his popular-scholarly history of the Diocese of Zagreb, ${ }^{1}$ but did not devote much attention to it. If it weren't for those few documents, the only clue we would have of an expulsion having taken place is that until 1458 several persons were mentioned as canons of Zagreb, and afterwards they weren't. Thankfully, now that we know of it, we can discern its reasons and consequences. Due to the general lack of literature on this subject, most of the data in this paper comes from the primary sources, some published, others unpublished. A lion's share of them comes from the

\footnotetext{
* Tomislav Matić, Catholic University of Croatia, Ilica 242, 10000 Zagreb, Croatia, E-mail: tomislav. matic@unicath.hr

1 Andrija Lukinović, Zagreb - devetstoljetna biskupija [Zagreb: The $900^{\text {th }}$ anniversary of its bishopric] (Zagreb: Glas Koncila, 1995), 128.
} 
seventh volume of the collection Monumenta historica Episcopatus Zagrabiensis, ${ }^{2}$ and the second volume of Monumenta historica liberae regiae civitatis Zagrabiae, ${ }^{3}$ but others are scattered through a number of other collections or archives from Vienna to Budapest.

The objective of this paper will be to determine what led to the expulsion, in what circumstances it took place, and who were the persons involved in it. Although it touches on problems arising from ethnicity, I shall not delve into the matter of ethnic identities in the late Middle Ages. I shall rather concentrate on determining why "Germans" were treated as a distinct and somehow "different" group in a late medieval Slavonian ecclesiastical institution of a rank as high as a cathedral chapter. I shall concentrate on the expulsion itself and study its political causes and implications. I will try to track the careers of the expelled canons before and after the expulsion, study the conditions in the Diocese of Zagreb before and at the time when it occurred, and put the event in the context of the political situation in the Kingdom of Hungary. It should also be noted that, while the expelled canons did not all come from German lands - at least one of them was from what is now Slovenia (which also had a significant ethnically German population) - they certainly called themselves "Almani", meaning Germans. It would be more precise to call them subjects of the Holy Roman Empire, as they were different enough from the rest of the local clergy to be considered foreigners.

Throughout the first half of the $15^{\text {th }}$ century, the Diocese of Zagreb was, if not dominated, then certainly greatly influenced by Germans, or rather subjects of the Holy Roman Empire. From the turn of the century until the 1430s, its bishops, Everard (known under the German name of Eberhard in medieval charters) and John Alben, were Germans or of German extraction, ${ }^{4}$ and during the Habsburg-Jagiellonian succession war and the subsequent reign of Ladislaus V of Habsburg (r. 1440 - 1457), the diocese was under the control of the Counts of Celje, Frederick II and Ulrich II.

The Counts of Celje (known in international historiography under the German name for this Slovenian town - Cilli), originally lords of Žovnek, were a Styrian family that became prominent in the Kingdom of Hungary thanks to the personal connections between Count Herman II and King (later Emperor) Sigismund of Luxemburg. Most of northwestern Slavonia came under their rule at the turn of the $15^{\text {th }}$ century, and

\footnotetext{
2 Andrija Lukinović, ed., Monumenta historica episcopatus Zagrabiensis, vol. 7 (Zagreb: Kršćanska sadašnjost; Hrvatski državni arhiv, 2004) (hereafter: MHEZ 7).

3 Ivan Krstitelj Tkalčić, ed., Monumenta historica liberae regiae civitatis Zagrabiae, vol. 2 (Zagreb: Karl Albrecht, 1894) (hereafter: MCZ 2).

4 Regarding the Alben family and their relative Everard (John was his nephew on the distaff side), see Marija Karbić, "Velikaška obitelj Alben i njezina uloga u hrvatskoj povijesti” [The magnate family of Alben and its role in Croatian history], Godišnjak Njemačke zajednice / DG Jahrbuch 19 (2012): 11-29. See also: Lovorka Čoralić, "Ivan Alben - istaknuti zagrebački biskup njemačkoga podrijetla (1421.-1433. god.)" [Ivan Alben, a prominent bishop of Zagreb of German origin], Godišnjak Njemačke zajednice / DG Jahrbuch (1998): 19-24. For the said bishops, see: Andrija Lukinović, "Biskup Eberhard (1397-1406/ 1410-1419)" and idem, "Biskup Ivan Alben (1421-1433)", in: Zagrebački biskupi i nadbiskupi, ed. Franko Mirošević (Zagreb: Školska knjiga, 1995), 163-175 and 181-186.
} 
they extended their control over the Diocese of Zagreb during the succession war and the interregnum that ensued. ${ }^{5}$ Queen Elizabeth of Hungary $(1409-1442)$ conferred the right of patronage over it on the counts in $1440,{ }^{6}$ and they conquered most of the episcopal estates in 1445. ${ }^{7}$ Bishop Benedict of Zvolen (r. 1440 - 1454) ruled under the counts' tutelage, ${ }^{8}$ and after his death in 1454 Ulrich II appointed his own chancellor, Balthasar Montschiedel, as bishop. ${ }^{9}$ The counts resolutely defended their right of patronage, to the extent of repulsing the pope's candidate for the bishopric, Thomas Himfi of Döbrönte, ${ }^{10}$ and King Ladislaus V claimed that Thomas had lied to him about having the count's approval for being made bishop. ${ }^{11}$

This situation reflected itself onto the Chapter of Zagreb as it had become open to Holy Roman subjects. For example, Count Frederick II had some of his clerks appointed as its canons, ${ }^{12}$ and King Ladislaus V rewarded his Austrian chancellor Stephen Aloch of Stein with its lectorate. ${ }^{13}$ It is therefore not surprising that by 1458 , Germans made up a significant portion of the chapter. However, it should be also noted that, as far as we know, before that year there had not been any complaints regarding that. To explain what led to their expulsion, we have to consider another contender for the Diocese of Zagreb - Bishop Demetrius Čupor.

\footnotetext{
5 Bibliography on the Counts of Celje by far exceeds the limits of this paper. For further reading, see Robert Kurelić, "Pregled povijesti grofova Celjskih" [A brief history of the Counts of Celje], Historijski zbornik 59 (2006): 201-216, and Suzana Miljan, "Grofovi Celjski i Nijemci, službenici njihovih utvrda u Zagrebačkoj i Križevačkoj županiji u kasnom srednjem vijeku (1385.-1456.)” [The Counts of Celje and Germans, retainers in their castles in the Counties of Zagreb and Karlovac during the late Middle Ages (1385-1456)], Godišnjak Njemačke zajednice / DG Jahrbuch 20 (2013): 11-22, and the literature listed therein. For the counts' actions in medieval Slavonia, see Nada Klaić, Zadnji knezi Celjski v deželah Sv. krone [The last Counts of Celje in the lands of the Holy Crown] (Celje: Prese založba, 1991). The latter work has its weaknesses and biases; regarding that, see a critique in Tomislav Raukar, "Grofovi Celjski i hrvatsko kasno srednjovjekovlje" [The Counts of Celje and late medieval Croatia], Historijski zbornik 36 (1983): 113-140.

6 Vilmos Fraknói, ed., Oklevéltár a Magyar király kegyuri jog történetéhez [Chartulary related to the ius patronii of the Hungarian kings] (Budapest: Magyar Tudományos Akadémia, 1899), 18-19, doc. XI.

7 Tamás Pálosfalvi, “Cilleiek és Tallóciak: küzdelem Szlavóniáért (1440-1448)" [The Counts of Celje and the Tallóci: Struggle for Slavonia (1440-1448)], Századok 134 (2000), 74ff.

$8 \quad$ See Iohannes Vitéz de Zredna. Opera quae supersunt, ed. Iván Boronkai (Budapest: Akadémiai Kiadó, 1980), 149-153, doc. 72.

$9 \quad$ Franz Krones, Die Freien von Saneck und ihre Chronik (Graz: Leuschner und Lubensky, 1883), 107.

10 Thomas was formally elected by the Chapter, confirmed by the pope and consecrated in Rome; see MHEZ 7, 259, doc. 245 and 265-266, docs. 251 and 253.

11 MHEZ 7, 281, doc. 263.

12 MHEZ 7, 1, doc 1 and 21, doc. 26.

13 Karl Uhlirz, ed., Quellen zur Geschichte der Stadt Wien, part II: Regesten aus dem Archive der Stadt Wien, vol. 2: Verzeichnis der Originalurkunden der Städtischen Archives 1412-1457 (Vienna: Verlag und Eigenthum des Alterthums-Vereines zu Wien, 1900), 347-350, No. 3509, 3517, and 3520. Regarding Aloch, see Paul-Joachim Heinig, Kaiser Friedrich III. (1440-1493): Hof, Regierung und Politik, vol. 1 (Cologne; Weimar; Vienna: Böhlau Verlag, 1997), 581, 593, and 622-23.
} 
Demetrius stemmed from a wealthy noble family with estates in the southeast of the diocese. ${ }^{14}$ Previously a member of the Chapter of Zagreb, he was made bishop of Knin in 1438, but was postponing his investiture and continued holding his offices in Zagreb, claiming that his diocese was too poor to support him, allegedly due to Ottoman incursions. ${ }^{15}$ As the Jagiellonian party did not recognize Benedict of Zvolen as bishop during the succession war, ${ }^{16}$ the part of the diocese under its control was governed by Ban Matko Talovac, who appointed Demetrius Čupor as its bishop in late $1444 .{ }^{17}$ This started what would become an extremely protracted lawsuit at the Apostolic Curia, but as the Counts of Celje had conquered most of the diocese, Demetrius could do little more than file complaints at the papal court. ${ }^{18}$

That changed when the Hunyadi rebellion against King Ladislaus V broke out in 1457 , followed shortly afterwards by the king's death. ${ }^{19}$ In the succession crisis that ensued, Balthasar Montschiedel knew that his position was hopeless, as the power of the Counts of Celje had been crumbling ever since the assassination of their last male descendant, Ulrich II, by the Hunyadis in $1456 .{ }^{20}$ As he could not hope to get in the Hunyadi party's good graces, Balthasar offered his support to a pro-Habsburg claimant to the Hungarian throne - Duke William III of Saxony, husband of Ladislaus V's sister Anna. He went to Vienna and met with the duke's agents there, ${ }^{21}$ but William

14 Regarding the Čupor family, see Zrinka Nikolić Jakus, “Obitelj Čupor Moslavački” [The family of Čupor Moslavački], Radovi Zavoda za znanstvenoistraživački i umjetnički rad u Bjelovaru 4 (2011): 269-300, and Támas Pálosfalvi, The Noble Elite in the County of Körös (Križevci) 1400-1526 (Budapest: MTA Bölcséstudományi Kutatóközpont, Törtenéttudományi Intézet, 2014), 89-96.

15 Pál Lukcsics, ed., Diplomata pontificum saeculi XV, vol. 2: Eugenius Papa IV. (1431-1447), Nicolaus Papa V. (1447-1455) (Budapest: Magyar Tudományos Akadémia, 1938), 172, No. 598; Andrija Lukinović, ed., Monumenta historica episcopatus Zagrabiensis, vol. 6 (Zagreb: Kršćanska sadašnjost; Hrvatski državni arhiv, 1994), 567-568, doc. 534 and 588, doc. 542. See also Andrija Lukinović, "Biskup Demetrije Čupor (1465-1466)”, in: Zagrebački biskupi i nadbiskupi, ed. Franko Mirošević (Zagreb: Školska knjiga, 1995), 203.

16 MHEZ 7, 32, docs. 35-36; György Bónis, Szentszéki regeszták - Iratok az egyházi bíráskodás történetéhez a középkori Magyarországon [Registers of the Holy See: Documents for the history of Church jurisdiction in medieval Hungary] (Budapest: Püski Kiadó, 1997), 307, No. 2563.

17 Pálosfalvi, “Cilleiek és Tallóciak”, 70-73.

18 Andrija Lukinović, "Biskup Benedikt de Zolio (1440-1454)”, in: Zagrebački biskupi i nadbiskupi, ed. Franko Mirošević (Zagreb: Školska knjiga, 1995), 193-194; Lino Gómez Canedo, Un español al servicio de la Santa Sede: Don Juan de Carvajal, cardenal de Sant'Angelo, legado en Alemania y Hungria (1399?-1469) (Madrid: Consejo superior de investigaciones cientificas, Instituto Jeronimo Zurita, 1947), 262-263.

19 Rudolf Urbánek, Konec Ladislava Pohrobka [The End of Ladislaus the Posthumous] (Prague: Česká akademie věd a umění, 1924), 100-101; Pál Engel, The Realm of St. Stephen, trans. Tamás Pálosfalvi (London; New York: I.B. Tauris Publishers, 2001), 297; András Kubinyi, Matthias Rex, trans. Andrew T. Gane (Budapest: Balassi Kiadó, 2008), 28-29.

20 Regarding the assassination, see Klaić, Zadnji knezi Celjski, 102-104. The Chronicle of the Counts of Celje offers a dramatic account of how the counts' estates were torn apart after Ulrich's death; see Krones, Die Freien von Saneck, 127ff.

21 Vilmos Fraknói, “Anna szász herczegné magyar trónkövetelő 1458-ban” [Princess Anna of Saxony as a claimant to the Hungarian throne in 1458], Századok 31 (1897): 3-6. 
was not particularly interested in claiming the Hungarian throne. ${ }^{22}$ Meanwhile, Demetrius stood by the Hunyadis and very likely joined their rebellion, taking control of Zagreb in January $1458 .{ }^{23} \mathrm{He}$ was supported by the then leader of the Hunyadi party, Matthias Hunyadi’s maternal uncle Michael Szilágyi. In January 1458, Matthias was elected as king of Hungary and Demetrius continued to serve him. ${ }^{24}$ During the Ottoman incursion into Syrmia in the summer of 1458, Demetrius's troops fought in King Matthias's army. ${ }^{25}$ By May 1459, he was appointed the king's chaplain. ${ }^{26}$

When he took control of the Diocese of Zagreb, Demetrius found its chapter filled with dignitaries appointed by the late Habsburg king and the Counts of Celje, who had been denying him what he saw as his bishopric for the past thirteen years. What followed was what appears to be one of the most comprehensive acts of ethnic intolerance in late medieval Slavonia. On November 23, 1458, seven canons of the Chapter of Zagreb protested before Pope Pius II (r. 1458 - 1464) that they had been expelled from the chapter by Bishop Demetrius for no other reason than because they were Germans. These were the lector John Aloch of Stein, the cantor Bartholomew of Stein, the archdeacon of Vrbovac Marquard Stelling, the archdeacon of Varaždin Sigismund of Opava, and canons Jacob of Laško, Frederick Abprecher, and Nicholas Toldner. They testified that they were told that the king had passed a law forbidding foreigners from holding lay or ecclesiastical offices in the Kingdom of Hungary, and that such offices were to be taken away from foreigners who held them and given to Hungarians. Indeed, the benefices held by the Germans were immediately given to Slavonian and Hungarian claimants, namely to Ladislaus of Gora, George of Gora, John Milay, Paul of Pakrac, Stephen of Stubica, Michael of Podgrađe, Giles of Óvár, and Demetrius of Sredice. Especially striking is the statement that the bishop was acting with the assistance of the remainder of the Chapter. ${ }^{27}$ This means that he didn't force his will on the canons, but that the Chapter itself was divided and that the rest of the canons wanted to get rid of their German colleagues.

22 William was more interested in obtaining the Bohemian throne; see Frederick Gotthold Heymann, George of Bohemia - King of Heretics (Princeton, NJ: Princeton University Press, 1965), 154.

23 Hungary (hereafter: HU) - Magyar Nemzeti Levéltár Országos Levéltára (hereafter: MNL), Budapest - Diplomatikai Fényképgyüjtemény (hereafter: DF), 231 401; see also HU-MNL - Diplomatikai Levéltár - Mohács Előtti Gyüjtemény (hereafter: DL), 34211.

24 MHEZ 7, 338, doc. 318.

25 He rewarded one of his men who was wounded in the siege of Slankamen during this campaign; see MHEZ 7, 362, doc. 339. For the Ottoman campaign in Serbia and incursion into Syrmia, see: Aleksije Akimovič Olesnicki, "Mihajlo Szilágyi i srbska despotija” [Michael Szilágyi and the Serbian Despotate], Rad hrvatske akademije znanosti i umjetnosti 276 (1943), 29 and Tamás Pálosfalvi, From Nicopolis to Mohács: A History of Ottoman-Hungarian Warfare, 1389-1526 (Leiden; Boston: Brill, 2018), 196-197.

26 HU-MNL-DF, 288157.

27 MHEZ 7, 356-361, docs. 336-337. Lukinović thought that the entire Chapter refused to recognize Demetrius as bishop and that he therefore tried to fill it with his adherents. See Lukinović, Zagreb devetstoljetna biskupija, 128. Also note, Archdeacon Sigismund's surname was spelled "Tappenawcz", "Damepnawer", and "Topnaw" in the sources, so I assumed that his place of origin could be Opava in Moravia (in German: Troppau). This is only my guess, however, as no document cited in this paper explains his origins. 
In the late Middle Ages, chapters throughout Christian Europe were trying to limit the number of foreigners holding their offices and benefices, or to exclude them outright. ${ }^{28}$ The Kingdom of Hungary was no exception in this matter. Throughout the $15^{\text {th }}$ century, there were attempts of excluding foreigners from the Hungarian Church and administration, ${ }^{29}$ and anti-German pogroms were not unheard of. ${ }^{30}$ Even Vitus Hündler, the episcopal vicar of the famous humanist and bishop of Pécs Janus Pannonius, noted that his master could not stand him because he hated Germans. ${ }^{31}$ This is less paradoxical than it sounds, as Renaissance Humanism, with its rediscovery of Classical patriotic and ethnographical literature, contributed greatly to the rise of xenophobia. ${ }^{32}$ It should be said that Germans often made up a dominant group within Hungarian urban settlements, and would sometimes take steps to ensure that it stayed so; in Sibiu, for example, immigration of non-Germans was actively impeded. ${ }^{33}$ In any case, although Germans were a significant minority in the Kingdom of Hungary, there certainly was an air of distinctness about them.

It seems that there was an outburst of anti-German sentiments in late 1456, at the time when Ulrich of Celje was murdered, ${ }^{34}$ and it was probably exacerbated by the Hunyadi rebellion in the following year. In January 1458, upon the election of Matthias Corvinus to the throne, the newly appointed governor of the Kingdom of Hungary, Michael Szilágyi, passed a law forbidding the king to grant ecclesiastical benefices to

28 Tamás Fedeles, "Ausländer in den ungarischen Dom- und Stiftskapiteln während des Spätmittelalters (1301-1526)", Specimina nova. Pars prima, Sectio mediaevalis 4 (2004): 77-78.

29 Fedeles, “Ausländer", 79-80. See also Engel, The Realm, 205-206, 211ff, and 279-280.

30 There was such a pogrom in Buda in 1438. See János Thuróczy, Chronicle of the Hungarians, trans. and ed. Frank Mantello and Pál Engel (Bloomington, IN: Indiana University Research Institute for Inner Asian Studies, 1991), 200. It could be claimed that this occurrence had its social or economic reasons, but then again, every pogrom in history did. The Buda case is especially telling of how sharply Germans were divided from the rest of the population. See Martyn Rady, "The Government of Medieval Buda”, in: Medieval Buda in Context, ed. Balázs Nagy et al. (Leiden; Boston: Brill, 2016), 303-321.

31 Jószef Koller, Historia Episcopatus Quinqueecclesiarum, vol. 4 (Bratislava: Joannes Michael Landerer, 1796), 345-346.

32 Gábor Almási, “Constructing the Wallach 'Other' in the Late Renaissance”, in: Whose Love of Which Country? Composite States, National Histories and Patriotic Discourses in Early Modern East Central Europe, ed. Balázs Trencsényi and Márton Zászkaliczky (Leiden and Boston: Brill, 2010), 91130.

33 Katalin Szende, "Integration through Language: The Multilingual Character of Late Medieval Hungarian Towns", in: Segregation - Integration - Assimilation: Religious and Ethnic Groups in the Medieval Towns of Central and Eastern Europe, ed. Derek Keene, Balázs Nagy, and Katalin Szende (Farnham: Ashgate, 2009), 207-208.

34 See Thuróczy, Chronicle, 253. Perhaps related to this, the contemporary poet and eyewitness of these events Michael Beheim testified that one of the German lords captured by the Hunyadis at the time of the count's murder was publicly humiliated and forced to ride a sow. See Theodor Georg von Karajan, ed., “Zehn Gedichte Michael Beheim's zur Geschichte Oesterreichs und Ungerns”, in: Quellen und Forschungen zur Vaterländischen Geschichte, Literatur und Kunst (Vienna: Wilhelm Braumüller, 1849), 62. 
foreigners. ${ }^{35}$ A similar law was passed in 1453, but with a limited duration; ${ }^{36}$ Szilágyi's legislation extended it indefinitely. On June 8, King Matthias confirmed a law from 1439 prescribing that the king would appoint only Hungarians to all ecclesiastical and lay offices. ${ }^{37}$ Royal patronage over ecclesiastic offices was further extended by a law prescribing that only the king had the right to appoint abbots and provosts, invalidating all other lay patronages over monastic institutions. ${ }^{38}$ The expulsion of Germans from the Chapter of Zagreb occurred sometime between September 5, when the expelled canons were still members of the Chapter and participated in its proceedings (in fact, a notarial charter in favour of the Chapter was issued in Sigismund of Opava's residence), ${ }^{39}$ and November 23, 1458, when they presented their grievance to the pope. Therefore, all of those laws were in force at the time.

That means that there was at least some truth to Demetrius's and his accomplices' justification of their act. As the mentioned German canons, who had received their canonries from the Counts of Celje, counted as foreigners as far as the Hunyadi party was concerned, such laws made their position at least somewhat uncertain. The law from 1439 was probably the one that Demetrius and his adherents cited as an excuse for expelling them, considering that the expelled canons repeated it almost verbatim in their complaint to the pope. ${ }^{40}$ It also seems that the bishop was acting with King Matthias's support, as Demetrius of Sredice, who had usurped the archdeaconry of Varaždin from one of the expelled Germans, Sigismund of Opava, later stated that he was presented to the archdeaconry by the king, who was acting as its legal patron. However, it seems that he was aware that his position wasn't exactly legal, as in $\mathbf{1 4 6 0}$ he asked the pope to confirm his possession of that office and to pardon him for all illegal actions he might have committed while obtaining it. ${ }^{41}$

This is important because none of King Matthias's laws prescribed replacement of already installed foreign beneficiaries with Hungarians, but simply limited the king in awarding future vacant benefices. A harsher law, prescribing exactly such replacement, was passed by King Wladislas in 1444 , during the succession war, ${ }^{42}$ but Matthias didn't confirm it. It seems that not only Demetrius of Sredice, but also the other

\footnotetext{
35 János Bak et al., trans. and ed., The Laws of the Medieval Kingdom of Hungary / Decreta regni mediaevalis Hungariae, vol. 3: 1458-1490 (Los Angeles: Charles Schlacks, Jr., 1996), 2, § VII.

36 Ferenc Döry, Györgyi Bónis, and Vera Bácskai, ed., Decreta Regni Hungariae / Gesetze und Verordnungen Ungarns 1301-1457 (Budapest: Akadémiai Kiadó, 1976), 376, § III.

37 Döry, Bónis, and Bácskai, Decreta Regni, 288, $₫$ V.

38 Bak et al., The Laws, 8, § XLVII.

39 MHEZ 7, 346-347, doc. 326.

40 ...quod alienigenis et exteris hominibus cuiuscumque nationis et lingwai (!) existant, quecumque ecclesiastice et seculars dignitates maiores et minores, ad tempus vel in perpetuum in regno Hungarie non conferantur, sed Ungaris tantum dentur... (MHEZ 7, 357); compare with: Item alienigenis et forensibus hominibus, cuiuscunque nationis et linguagii existant, officia in ipso regno nostro non committemus... vel quascunque ecclesiasticas vel seculares dignitates ad tempus vel imperpetuum extraneis vel forensibus, nisi hominibus Hungaris conferemus... (Döry, Bónis and Bácskai, Decreta Regni, 288, § V).

41 MHEZ 7, 384-385, docs. 359-360.

42 Döry, Bónis, and Bácskai, Decreta Regni, 333, § XXXII.
} 
usurpers were well aware of the fact that their possession of the expelled Germans' benefices was spurious at best, considering that they were trying to legalize it. Michael of Podgrađe sought to secure his position by claiming that the canon whose benefice he took, Frederick Abprecher, had been absent from the Chapter for too long, and a charter was issued and affixed to the cathedral doors ordering him to return, because otherwise his benefices would be declared forfeit. Frederick claimed in 1461 in his appeal to the pope that he had not been given enough time to respond to the summons, and that the judges in charge of his case, especially the aforementioned Demetrius of Sredice, were biased anyway. ${ }^{43}$ In short, it was merely a show trial meant to legally deprive him of the benefice he had already lost.

The expelled lector, John Aloch of Stein, was probably a relative of a former chancellor of King Ladislaus V, Stephen Aloch. The office was probably passed to him by Stephen in $1454 .{ }^{44}$ The cantor, Bartholomew of Stein, was probably also related to the same family, and was by his own admission presented to the benefice by Count Frederick of Celje. ${ }^{45}$ Marquard Stelling, doctor of medicine, and Jacob of Laško, doctor of canon law, had been members of the Chapter since at least 1452, when Bishop Benedict was still alive. ${ }^{46}$ Sigismund of Opava was already an archdeacon in $1453 .{ }^{47}$ One of the canons, Frederick Abprecher, witnessed the issuing of a charter by the Chapter of Zagreb in August 1441 regarding its dealings with the Counts of Celje; at that time, he was the parish priest of Šmartno ob Paki and Šentrupert in Styria. ${ }^{48} \mathrm{He}$ was probably acting as one of the counts' emissaries, which is corroborated by the fact that one of his colleagues was George Glaynar, a prominent retainer of the family. ${ }^{49}$

Most of the expelled Germans had been members of the Chapter since at least $1454,{ }^{50}$ and it is certain that they were introduced to their benefices by the counts' bishops. It is therefore likely that Demetrius did not see his opponents primarily as Germans, but as supporters of his enemies. This might be supported by the case of Peter the

\footnotetext{
43 MHEZ 7, 415-416, doc. 391.

44 In that year, the office of lector was held by a person named John (see MHEZ 7, 265, doc. 251), probably identical to John of Stein who was mentioned as a member of the Chapter on June 28, 1454 (see ibid., 257, doc. 241).

45 MHEZ 7, 416-417, doc. 392.

46 MCZ 2, 224. Regarding Marquard, see also Tamás Fedeles, "Egy németalföldi orvosdoktor a középkori Magyarországon" [A doctor of medicine from the Low Countries in medieval Hungary], Orvostörténeti Közlemények 190-193 (2005), 190. See also Gyula Magyary-Kossa, Magyar orvosi emlékek. Értekezések a magyar orvostörténelem köréböl [Hungarian medical documents: Studies from Hungarian medical history] vol. 3 (Budapest: Magyar Orvosi Könyvkiadó Társulat, 1931), 93, No. 349. Jacob is referred to as "of Tiwer" or "Tiuer" in the cited documents, which is how Laško, or Tüffer in German, was often spelled in the $15^{\text {th }}$ century. See Anton Ožinger, "Dunajski študenti iz Laškega od 14. do 16. stoletja" [Students from Laško in Vienna (14th-16 ${ }^{\text {th }}$ centuries)], Časopis za zgodovino in narodopisje 47 (1976), No. 2: 276-278.

47 MCZ 2, 232.

48 Lajos Thallóczy, Samu Barabás, ed., Codex diplomaticus comitum de Blagay (Budapest: A Magyar Tudományos Akadémia Könyvkiadó-Hivatala, 1897), CXCIII, doc. VII.

49 Regarding Glaynar, see Miljan, “Grofovi Celjski”, 18.

50 See MHEZ 7, 257, doc. 241.
} 
German (Teutonicus), archdeacon of Kalnik, who was still a member of the Chapter in $1458,{ }^{51}$ but was mentioned to have resigned his office not long before February $1461 .^{52}$ Although it is alluring to assume that Peter was forced to resign, we have no reason to believe that he did not do so voluntarily, perhaps due to old age, as in 1467 he was mentioned as being deceased for quite some time. He bequeathed his personal properties - estates in the vicinity of Zagreb, a vineyard and a mill - to his nephew (sic!) Milica. ${ }^{53}$ The latter's very Slavic name might indicate that Peter was not really German, or at least that his family had become naturalized. Perhaps they belonged to the German community in nearby Gradec, which had been an established part of its urban population since at least the $14^{\text {th }}$ century. ${ }^{54}$ In any case, Bishop Demetrius and his supporters decided to leave Peter alone, as he was not among the expelled canons. A similar atmosphere prevailed in nearby Gradec after Count Ulrich's assassination, when the counts' German officials were no longer welcome there, but other Germans remained relatively unmolested..$^{55}$

Another reason why Demetrius targeted specifically those canons may have been because their positions were not canonically legal, at least if they had received their benefices after the death of Bishop Benedict. The aforementioned Peter the German was a member of the Chapter at least as early as $1450,{ }^{56}$ so he did not fall in that category. As we have already mentioned, the pope's candidate for the bishopric was Thomas Himfi, while Bishop Balthasar, appointed by the Counts of Celje, was not recognized by the Holy See. This cast a shadow of doubt on all of his collations. Their recipients were aware of this, and they later tried to legalize their status by obtaining a papal confirmation. ${ }^{57}$ But those of them who were not German continued to hold their benefices unmolested and, as we have seen, even some of the Germans who had received their benefices before Bishop Benedict's death were expelled. Demetrius probably could not afford to turn against the whole Chapter, and there were not many canons in it who had not received their benefices from the Counts of Celje. Considering the coinciding anti-foreigner sentiment, perhaps the Germans were simply easy targets.

It should also be considered that Demetrius had to reward the clerics who had supported him during his struggle to obtain the bishopric of Zagreb. Regarding this, the case of Demetrius of Sredice, master of arts and doctor of canon law, is especially interesting, considering that he had been an esteemed member of the Chapter and

\footnotetext{
51 MHEZ 7, 334, doc. 312.

52 MHEZ 7, 406, doc. 383.

53 Ivan Krstitelj Tkalčić, ed., Monumenta historica liberae regiae civitatis Zagrabiae, vol. 7 (Zagreb: Karl Albrecht, 1902) (hereafter: MCZ 7), 321-322 and 327-328.

54 Bruno Škreblin, “Ethnic Groups in Zagreb's Gradec in the Late Middle Ages”, Review of Croatian History 9 (2013), No. 1: 33-34.

55 Bruno Škreblin, "Nijemci na Gradecu sredinom i u drugoj polovici 15. st." [Germans in Gradec in the middle and the second half of the $15^{\text {th }}$ century], Godišnjak Njemačke zajednice / DG Jahrbuch 17 (2010): 40-50.

56 MHEZ 7, 187, doc. 181.

57 MHEZ 7, 415-418 and 422-424, docs. 392-393 and 400-401.
} 
served as the diocese's vicar in spiritualibus since at least September $1457,{ }^{58}$ and was yet one of the usurpers of the German canons' benefices. He was probably the bishop's "inside man", whose task was to secure the Chapter's support for him, and who was probably promised an additional benefice as a reward. Some of the usurpers occupying the expelled Germans' benefices' were supporters and servants of Demetrius or his family, such as Michael, parish priest of Podgrađe, a township owned by the Čupors. ${ }^{59}$ Indeed, Demetrius tried to secure a benefice for him as early as $1447 .{ }^{60} \mathrm{He}$ also sought other ways to compensate his adherents in 1458; for example, he secured the posts of papal chaplains for a couple of them. ${ }^{61}$ As for the rest of the usurpers, their connections to Demetrius are largely unknown, and some of them were not even from the Diocese of Zagreb. For example, Giles of Óvár was an altarist in the Gilded Chapel of Our Lady in Pécs in $1449,{ }^{62}$ and a canon of the cathedral chapter of Pécs in $1474 .^{63}$

It could be assumed that Demetrius did not expel the Germans only because of their ethnicity, but because of their adherence to the Counts of Celje and, ultimately, the Habsburgs, and because he needed to clear some posts in the Chapter for his own men. He needed the Chapter's loyalty if he wanted to rule the diocese, as he lacked the pope's confirmation and was deeply embroiled in the tumultuous internal politics of the Kingdom of Hungary. It seems that he indeed had reasons to doubt where some of the expelled canons' loyalties lay. The case of Frederick Abprecher is especially indicative. In his appeal to the pope, submitted in May 1461, Frederick stated that in Hungary, Church officials were allowed to be absent from their benefices if they served the emperor and king of Hungary, as he did. ${ }^{64}$ The fact that he included the title of emperor there could point to his involvement with the rebellion of 1459, during which, on February 17, rebels against King Matthias elected Emperor Frederick III as king of Hungary. ${ }^{65}$ Indeed, we find Abprecher in the emperor's service as early as 1457, holding the parish of Laško and serving as the imperial governor of Celje, which

\footnotetext{
58 See MHEZ 7, 325 and 343, docs. 304 and 323.

59 Regarding Podgrađe, the township below the castle of Košutagrad, see Nikolić Jakus, "Obitelj Čupor Moslavački”, 272 and 288-289, and Tajana Pleše, Petar Sekulić, “Jelengrad i Košutgrad - Dva moslavačka stara grada / Jelengrad and Košutgrad - Two Burgs in Moslavina”, Prilozi Instituta za arheologiju u Zagrebu 30 (2013): 84-86.

60 MHEZ 7, 119-120, doc. 117.

61 MHEZ 7, 338, doc. 318.

62 HU-MNL-DL, 14 227. The Gilded Chapel was erected next to the Pécs cathedral in the $14^{\text {th }}$ century; see Tamás Fedeles, “in dicta civitate Quinque Ecclesiensi de cetero sit studium generale’: Short History of the Medieval University of Pécs", in University and Universality: The Place and Role of the University of Pécs in Europe from the Middle Ages to Present Day, ed. Ágnes Fischer-Dárdai, István Lengvári, and Éva Schmelczer-Pohánka (Pécs: University Library of Pécs; Centre for Learning, 2017), 94-95.

63 Ernő Kammerer, Ferenc Döry, ed., Codex diplomaticus domus senioris comitum Zichy de Zich et Vásonkeö, vol. 11 (Budapest: Magyar Törtenélmi Társulat, 1915), 157-160, doc. 86.

64 MHEZ 7, 415, doc. 391.

65 Engel, The Realm, 299; Kubinyi, Matthias Rex, 63-64.
} 
the emperor took over after the death of Count Ulrich ${ }^{66}$ It seems that Abprecher was also, through his brother John, connected to Countess Catherine Branković, Count Ulrich's widow, as John Abprecher was mentioned as her castellan of the Samobor Castle in $1459 .{ }^{67}$ It is therefore possible that at least some of the German canons either actively resisted Demetrius' takeover of the diocese, or that they hoped to regain their benefices with the emperor's assistance. This assumption is corroborated by the pope's choice of persons who were supposed to reinstall the expelled canons - the bishop of Passau, the provost of the collegiate chapter of St Stephen in Vienna, and the Cistercian abbot of Kostanjevica na Krki, all of them subjects of Emperor Frederick. ${ }^{68}$ Indeed, Bishop Ulrich von Nussdorf of Passau was the emperor's adviser and later imperial chancellor. ${ }^{69}$ Pope Pius II, himself a former employee of the emperor, knew very well whom he could trust to act in the emperor's favour. ${ }^{70}$

It should be noted that most of the German canons did not stay expelled for very long. Whether thanks to the pope's orders or to their own devices, most of them were back in the Chapter by 1460 . According to the Liber rubeus, which contains oaths and proclamations of the Chapter of Zagreb, John and Bartholomew of Stein, Sigismund of Opava, and Jacob of Laško once again became regular members of the Chapter, participating in its proceedings and personally signing its decisions. We still find them there in $1467 .^{71}$ Jacob of Laško was among the most active of the lot. He regularly took part in the Chapter's affairs, ${ }^{72}$ in 1468 he participated in some financial transactions, ${ }^{73}$ and in 1469 an inhabitant of the nearby city of Gradec was condemned by the municipal authorities for stealing some money from him. ${ }^{74} \mathrm{He}$ was still a canon when guns were distributed to members of the chapter in $1473 .{ }^{75}$ Bartholomew of Stein was also quite active. In 1469, he and some other canons sued a priest over some tithes, ${ }^{76}$ and by 1472 he was elected the Chapter's vicar in spiritualibus. ${ }^{77}$ He was still cantor in $1475,{ }^{78}$ and in 1476 , when he was mentioned togeth-

66 Božo Otorepec, “Grb trga Laško” [Coat of arms of the Laško marketplace], Časopis za zgodovino in narodopisje 47 (1976), No. 2: 299.

67 Suzana Miljan, "Grofovi Celjski i Nijemci”, 16-17.

68 MHEZ 7, 359, doc. 337. The digest here mistook Passau for Padua.

69 Heinig, Kaiser Friedrich, 655ff.

70 Before being elected pope, Pius, or rather Enea Silvio Piccolomini, was a secretary in the Imperial chancery. See Heinig, Kaiser Friedrich, 639ff.

71 MCZ 2, 276-277 and 318.

72 MCZ 2, 310, doc. 252.

73 Ivan Krstitelj Tkalčić, ed., Monumenta historica liberae regiae civitatis Zagrabiae, vol. 10 (Zagreb: Karl Albrecht, 1904), 269.

$74 \quad$ MCZ 7, 344.

75 MCZ 2, 360, doc. 290.

76 Jakov Stipišić, Miljen Šamšalović, “Isprave u Arhivu Jugoslavenske akademije (Nastavak - do smrti kralja Matije Korvina)" [Documents in the Archive of the Yugoslav Academy (Continued: until the death of Matthias Corvinus)], Zbornik Historijskog instituta Jugoslavenske akademije 3 (1960): 609, No. 2684.

77 MCZ 2, 342-343, doc. 276.

78 MCZ 2, 364, doc. 294. 
er with a certain lector John, perhaps John Aloch. ${ }^{79}$ He died sometime before June $1484 .{ }^{80}$ Unlike them, most of the usurpers, such as the aforementioned Giles of Ovarr, did not continue their careers in the Chapter of Zagreb.

The German canons who did not manage to regain their offices in Zagreb were most likely in some way connected to Emperor Frederick, either by having been Habsburg supporters since the time of Ladislaus $\mathrm{V},{ }^{81}$ or by becoming such during the rebellion of 1459. One of them, Nicholas Tolduer, died soon afterwards, before February 1463, and it seems that he had by then managed to secure another office for himself - a canonry in the collegiate chapter of Innichen, in Tyrol. ${ }^{82}$ Marquard Stelling became an imperial physician of Frederick III by 1463 and received the parish of Šmartno by Slovenj Gradec, in the emperor's domain. ${ }^{83}$ Later he ended up in the service of Archbishop Bernard von Rohr of Salzburg, who enfeoffed him with some estates. He was dead by February 1468, and he had bequeathed those estates, and other ones he had bought, to the Dominican monastery in Ptuj in exchange for the friars celebrating yearly requiem masses for the salvation of his soul ${ }^{84}$ It seems that the usurper of the archdeaconry of Vrbovec, George of Gora, was still holding that office in 1472. ${ }^{85}$

Frederick Abprecher was the most deeply involved with the emperor of all expelled German canons, so we have reason to believe that he opposed Bishop Demetrius's takeover of the diocese. After the expulsion, Abprecher took over the parish of Laško and became the emperor's adviser. He was mentioned as such in September 1462. ${ }^{86}$ As the imperial governor of Celje, he was present among the distinguished witnesses of Frederick III's establishment of the Diocese of Ljubljana in December $1461 .{ }^{87} \mathrm{He}$ was still in that office in 1466 , even expanding his authority. ${ }^{88} \mathrm{He}$ was financing the emperor extensively: in 1459, the imperial governor of the Ojstrica Castle pawned the estate of Grajska vas and several others to him and his brother Nicholas. ${ }^{89}$ Frederick

\footnotetext{
79 MCZ 2, 380.

80 MCZ 2, 427, doc. 338.
}

81 Frederick III was a serious candidate for the Hungarian throne after Ladislaus's death (he was the late king's second cousin once removed). See Kubinyi, Matthias Rex, 30.

82 Repertorium Germanicum Online (hereafter: RG), VIII 03453, last accessed on April 25, 2020, http://rg-online.dhi-roma.it/RG/8/3453.

83 RG VIII 04618, last accessed on April 25, 2020, http://rg-online.dhi-roma.it/RG/8/4618.

84 Austria - Österreichisches Staatsarchiv, Haus-, Hof- und Staatsarchiv, Allgemeine Urkundenreihe, doc. 1468 II 07. Bernhard was archbishop from 1466. See Konrad Eubel, Hierarchia catholica medii aevi, vol. 2 (Münster: Typis Librariae Regensbergianae, 1914), 228.

85 MCZ 7, 401.

86 Joseph Chmel, Regesta chronologico-diplomatica Friderici III. Romanorum imperatoris (regis IV.), vol. 2 (Vienna: Carl Gerold's Sohn: 1859), 394, No. 3939.

87 "Diplomatarij (nadaljevanje)" [Diplomata (continued)] (author unknown), Zgodovinski zbornik 1 (1888), No. 2: 22, doc. A.

88 Chmel, Regesta 2, 482, No. 4711. See also: Janez Parapat, “Doneski k zgodovini kranjskih mest. II: Kočevje" [Contributions to the history of Carniolan towns. II: Kočevje], Letopis Matice slovenske 5 (1874): 81.

89 Regesta Imperii Online, last accessed on April 25, 2020, http://www.regesta-imperii.de/id/145901-11_1_0_13_18_0_100_100. 
was leasing from the emperor the estates of Laško and Žebnik, and the gubernatorial office of Radeče in 1465 and 1466, ${ }^{90}$ and from 1466 to 1468 the gubernatorial offices of Kočevje and Kočevska Reka together with his brothers John and Nicholas. ${ }^{91}$ Abprecher died sometime before February 1472, and before his death he bequeathed some of his estates in the town of Celje and elsewhere to the establishment of a foundation for regular requiem masses for the salvation of his soul, to be celebrated at the local Franciscan monastery. His last will was executed by his brother John. ${ }^{92}$

As for Sigismund of Opava, his involvement was not with the emperor, but with Catherine Branković Cantacuzena, widow of Count Ulrich II of Celje. He was her chaplain, ${ }^{93}$ and after he was expelled from the Chapter he probably went to Varaždin, which was then still in the countess's hands. ${ }^{94}$ In September 1459, he represented her before the county assembly of Varaždin together with the castellan of the Varaždin Castle, delivering King Matthias's charter granting her and her subjects immunity from the local courts. ${ }^{95}$ As we have seen, Sigismund was back in the Chapter by 1460, which is logical, as Catherine's power was crushed by the mercenary captain-turned-magnate John Vitovec, and she fled to Dubrovnik in $1461 .^{96}$ There was no reason for Sigismund to continue supporting her. As John Vitovec was Bishop Demetrius's ally, who played a crucial role in his taking over of the diocese, ${ }^{97}$ it is no wonder that he thought Sigismund deserving of expulsion. Demetrius of Sredice, who usurped Sigismund's office, managed to remain one of the most influential members of the Chapter, being elected vicar again in $1464 .{ }^{98} \mathrm{He}$ did everything he could to secure the archdeaconry of Varaždin for himself, including paying the annate to the Apostolic Camera in July $1460 .{ }^{99}$ He held it for a year, but wasn't mentioned as an archdeacon afterwards. Sigismund was still archdeacon of Varaždin in 1471, when he, together with Cantor Batholomew of Stein and one other archdeacon represented

90 Jože Koropec, “Žebnik, Radeče in Svibno do 17. stoletja” [Žebnik, Radeče, and Svibno before the $17^{\text {th }}$ century], Časopis za zgodovino in narodopisje 50 (1979), No. 1-2: 60.

91 Georg Widmer, Urkundliche Beiträge zur Geschichte des Gottscheerländchens (1406-1627) (Vienna: Verein der Deutschen aus Gottschee in Wien, 1931), 7 and 33-34.

92 Slovenija - Zgodovinski arhiv Celje - Minoritski (1428-1762), L 6 Min and L 12 Min, available at Monasterium.net, last accessed on April 16, 2020, http://monasterium.net:8181/mom/SI-ZAC/Minoritski/SI_ZAC_L_6_Min/charter?q=Abprecher and http://monasterium.net:8181/mom/SI-ZAC/ Minoritski/SI_ZAC_L_12_Min/charter?q=Abprecher.

93 MCZ 2, 260. See also Suzana Miljan, "Grofovi Celjski, njihovi službenici njemačkog porijekla i Zagorsko kneštvo (comitatus Zagoriensis) krajem srednjeg vijeka (1397.-1456.)” [The Counts of Celje, their retainers of German origin, and the County of Zagorje (comitatus Zagoriensis) in the late Middle Ages (1397-1456)], Godišnjak Njemačke zajednice / DG Jahrbuch 19 (2012): 114, and Klaić, Zadnji knezi Celjski, 78.

94 Catherine remained in possession of Varaždin until 1460 at the latest. See Tamás Pálosfalvi, "Vitovec János. Egy zsoldoskarrier a 15. századi Magyarországon” [John Vitovec: A mercenary career in 15th-century Hungary], Századok 135 (2001): 441 and 456.

95 HU-MNL-DL, 103658.

96 Pálosfalvi, “Vitovec János”, 455-456.

97 HU-MNL-DL, 34211.

98 MHEZ 7, 510, doc. 452.

99 MHEZ 7, 396-397, docs. 370-371. 
the Chapter in dealings with the nearby lords, ${ }^{100}$ and he was mentioned as such as late as $1472 . .^{101}$

From this interesting case we can conclude that the Chapter of Zagreb, despite being an ecclesiastical and therefore supranational institution, was wracked by internal dissent and affected by the political and ethnic divisions of the mid- $15^{\text {th }}$ century. The expulsion of its German canons in 1458 occurred partly due to practical reasons, as the new bishop was eager to get rid of his predecessors' appointees, but also partly because of politics, as some of the expelled canons supported the opponents of the Hunyadi party and the new king Matthias. We have seen that some of them were deeply involved with Emperor Frederick, who was formally an enemy of King Matthias, and with whom rebels against the latter sided in 1459. Those remained expelled even after all the others returned to the Chapter, and were never given their offices back. One of the expelled canons, Sigismund of Opava, was not involved with the emperor, but was in the service of Countess Catherine of Celje, who may have also been considered an enemy of Bishop Demetrius. He, however, returned to the Chapter once the countess was no longer a threat. One other, Frederick Abprecher, was connected to both Frederick III and the Counts of Celje, and the Chapter took extra steps to prevent his return. He also fought most fiercely, although ultimately unsuccessfully, to get his office back.

However, the real problem is why even those canons who did not collaborate with either the emperor or the countess were expelled. Was it a matter of opportunism on Bishop Demetrius's part, or were they perceived as natural enemies by him and the rest of the Chapter? The way they were treated may have depended purely on their ethnicity, or rather on them being "different" than the rest of the canons. Nevertheless, it could also be that their connections to Bishop Demetrius's opponents or their past misdeeds are unknown to us. In this context, it is relevant to note that the only reason for the expulsion that Demetrius and his accomplices gave to the expelled canons was that they were foreigners, and as such unacceptable in their offices. It is worth noting that such "neutral" canons returned to the Chapter quite quickly, and that they were once again its distinguished members, who regularly participated in the Chapter's business and were trusted with important issues. Although we do not know whether this tragic affair left a mark on the relations within the Chapter, it seems that the matter resolved itself quickly. Still, it indicates that Germans had by the mid- $15^{\text {th }}$ century become "the other" not only in the political life of the Kingdom of Hungary, but within its Church as well.

\footnotetext{
100 MCZ 2, 333, doc. 269.

101 MCZ 2, 346.
} 


\section{Unpublished Sources}

Austria - Österreichisches Staatsarchiv, Haus-, Hof- und Staatsarchiv, Allgemeine Urkundenreihe

Hungary - Magyar Nemzeti Levéltár Országos Levéltára, Budapest - Diplomatikai Fényképgyüjtemény (HU-MNL-DF)

Hungary - Magyar Nemzeti Levéltár Országos Levéltára, Budapest - Diplomatikai Levéltár - Mohács Előtti Gyüjtemény (HU-MNL-DL)

Slovenia - Zgodovinski arhiv Celje - Minoritski (1428-1762), Monasterium.net. Last accessed on April 16, 2020. https://icar-us.eu/cooperation/online-portals/monasterium-net/.

\section{Published Sources and Literature}

Almási, Gábor. "Constructing the Wallach 'Other' in the Late Renaissance”. In: Whose Love of Which Country? Composite States, National Histories and Patriotic Discourses in Early Modern East Central Europe, ed. Balázs Trencsényi and Márton Zászkaliczky, 91130. Leiden; Boston: Brill, 2010.

Bak, János M.; Domonkos, Leslie S., trans. and ed. The Laws of the Medieval Kingdom of Hungary / Decreta regni mediaevalis Hungariae, vol. 3: 1458-1490. Los Angeles: Charles Schlacks, Jr., 1996.

Bónis, György. Szentszéki regeszták - Iratok az egyházi bíráskodás történetéhez a középkori Magyarországon. Budapest: Püski Kiadó, 1997.

Boronkai, Iván, ed. Iohannes Vitéz de Zredna - Opera quae supersunt. Budapest: Akadémiai Kiadó, 1980.

Canedo, Lino Gómez. Un español al servicio de la Santa Sede: Don Juan de Carvajal, cardenal de Sant'Angelo, legado en Alemania y Hungria (1399?-1469). Madrid: Consejo superior de investigaciones cientificas, Instituto Jeronimo Zurita, 1947.

Chmel, Joseph. Regesta chronologico-diplomatica Friderici III. Romanorum imperatoris (regis IV.), vol. 2. Vienna: Carl Gerold’s Sohn: 1859.

Čoralić, Lovorka. "Ivan Alben - istaknuti zagrebački biskup njemačkoga podrijetla (1421.-1433. god.)”. Godišnjak Njemačke zajednice / DG Jahrbuch (1998): 19-24.

“Diplomatarij (nadaljevanje)" (author unknown). Zgodovinski zbornik 1 (1888), No. 2: 19-26.

Döry, Ferenc, Bónis, Györgyi; Bácskai, Vera, ed. Decreta Regni Hungariae / Gesetze und Verordnungen Ungarns 1301-1457. Budapest: Akadémiai Kiadó, 1976.

Engel, Pál. The Realm of St. Stephen, trans. Tamás Pálosfalvi. London; New York: I.B. Tauris Publishers, 2001.

Eubel, Konrad. Hierarchia catholica medii aevi, vol. 2. Münster: Typis Librariae Regensbergianae, 1914. 
Fedeles, Tamás. "Ausländer in den ungarischen Dom- und Stiftskapiteln während des Spätmittelalters (1301-1526)”. Specimina nova. Pars prima, Sectio mediaevalis 4 (2004): 73-100.

Fedeles, Tamás. “in dicta civitate Quinque Ecclesiensi de cetero sit studium generale’. Short History of the Medieval University of Pécs". In: University and Universality. The Place and Role of the University of Pécs in Europe from the Middle Ages to Present Day, ed. Ágnes Fischer-Dárdai, István Lengvári, and Éva Schmelczer-Pohánka, 75-106. Pécs: University Library of Pécs and Centre for Learning, 2017.

Fedeles, Tamás. "Egy németalföldi orvosdoktor a középkori Magyarországon”. Orvostörténeti Közlemények 190-193 (2005): 185-196.

Fraknói, Vilmos. “Anna szász herczegné magyar trónkövetelő 1458-ban”. Századok 31 (1897): 1-13.

Fraknói, Vilmos, ed. Oklevéltár a Magyar király kegyuri jog történetéhez. Budapest: Magyar Tudományos Akadémia, 1899.

Heinig, Paul-Joachim. Kaiser Friedrich III. (1440-1493): Hof, Regierung und Politik, vol. 1. Cologne; Weimar; Vienna: Böhlau Verlag, 1997.

Heymann, Frederick Gotthold. George of Bohemia - King of Heretics. Princeton, NJ: Princeton University Press, 1965.

Kammerer, Ernő; Döry, Ferenc, ed. Codex diplomaticus domus senioris comitum Zichy de Zich et Vásonkeő, vol. 11. Budapest: Magyar Törtenélmi Társulat, 1915.

Karajan, Theodor Georg von, ed. “Zehn Gedichte Michael Beheim's zur Geschichte Oesterreichs und Ungerns". In: Quellen und Forschungen zur Vaterländischen Geschichte, Literatur und Kunst, 1-65. Vienna: Wilhelm Braumüller, 1849.

Karbić, Marija. "Velikaška obitelj Alben i njezina uloga u hrvatskoj povijesti”. Godišnjak Njemačke zajednice / DG Jahrbuch 19 (2012): 11-29.

Klaić, Nada. Zadnji knezi Celjski v deželah Sv. krone. Celje: Prese založba, 1991.

Koller, Jószef. Historia Episcopatus Quinqueecclesiarum, vol. 4. Bratislava: Joannes Michael Landerer, 1796.

Koropec, Jože. “Žebnik, Radeče in Svibno do 17. stoletja”. Časopis za zgodovino in narodopisje 50 (1979), No 1-2: 51-77.

Krones, Franz. Die Freien von Saneck und ihre Chronik. Graz: Leuschner und Lubensky, 1883.

Kubinyi, András. Matthias Rex, trans. Andrew T. Gane. Budapest: Balassi Kiadó, 2008.

Kurelić, Robert. "Pregled povijesti grofova Celjskih”. Historijski zbornik 59 (2006): 201216.

Lukcsics, Pál, ed. Diplomata pontificum saeculi XV, vol. 2: Eugenius Papa IV. (1431-1447), Nicolaus Papa V. (1447-1455). Budapest: Magyar Tudományos Akadémia, 1938.

Lukinović, Andrija, ed. Monumenta historica episcopatus Zagrabiensis, vol. 6. Zagreb: Kršćanska sadašnjost; Hrvatski državni arhiv, 1994. 
Lukinović, Andrija. “Biskup Benedikt de Zolio (1440-1454)”. In: Zagrebački biskupi i nadbiskupi, ed. Franko Mirošević, 202-205. Zagreb: Školska knjiga, 1995.

Lukinović, Andrija. “Biskup Demetrije Čupor (1465-1466)”. In: Zagrebački biskupi i nadbiskupi, ed. Franko Mirošević, 189-197. Zagreb: Školska knjiga, 1995.

Lukinović, Andrija. "Biskup Eberhard (1397-1406 / 1410-1419)". In: Zagrebački biskupi i nadbiskupi, ed. Franko Mirošević, 163-175. Zagreb: Školska knjiga, 1995.

Lukinović, Andrija. “Biskup Ivan Alben (1421-1433)”. In: Zagrebački biskupi i nadbiskupi, ed. Franko Mirošević, 181-186. Zagreb: Školska knjiga, 1995.

Lukinović, Andrija. Zagreb - devetstoljetna biskupija. Zagreb: Glas Koncila, 1995.

Lukinović, Andrija, ed. Monumenta historica episcopatus Zagrabiensis, vol. 7. Zagreb: Kršćanska sadašnjost; Hrvatski državni arhiv, 2004.

Magyary-Kossa, Gyula. Magyar orvosi emlékek. Értekezések a magyar orvostörténelem köréböl, vol. 3. Budapest: Magyar Orvosi Könyvkiadó Társulat, 1931.

Miljan, Suzana. "Grofovi Celjski, njihovi službenici njemačkog porijekla i Zagorsko kneštvo (comitatus Zagoriensis) krajem srednjeg vijeka (1397.-1456.)”. Godišnjak Njemačke zajednice / DG Jahrbuch 19 (2012): 97-117.

Miljan, Suzana. "Grofovi Celjski i Nijemci, službenici njihovih utvrda u Zagrebačkoj i Križevačkoj županiji u kasnom srednjem vijeku (1385.-1456.)”. Godišnjak Njemačke zajednice / DG Jahrbuch 20 (2013): 11-22.

Nikolić Jakus, Zrinka. “Obitelj Čupor Moslavački”. Radovi Zavoda za znanstvenoistraživački i umjetnički rad u Bjelovaru 4 (2011): 269-300.

Olesnicki, Aleksije Akimovič. "Mihajlo Szilágyi i srbska despotija”. Rad hrvatske akademije znanosti i umjetnosti 276 (1943): 1-183.

Otorepec, Božo. “Grb trga Laško”. Časopis za zgodovino in narodopisje 47 (1976), No. 2: 292-307.

Ožinger, Anton. "Dunajski študenti iz Laškega od 14. do 16. stoletja”. Časopis za zgodovino in narodopisje 47 (1976), No. 2: 276-280.

Pálosfalvi, Tamás. “Cilleiek és Tallóciak: küzdelem Szlavóniáért (1440-1448)”. Századok 134 (2000): 45-98.

Pálosfalvi, Tamás. “Vitovec János. Egy zsoldoskarrier a 15. századi Magyarországon”. Századok 135 (2001): 429-472.

Pálosfalvi, Tamás. The Noble Elite in the County of Körös (Križevci) 1400-1526. Budapest: MTA Bölcséstudományi Kutatóközpont, Törtenéttudományi Intézet, 2014.

Pálosfalvi, Tamás. From Nicopolis to Mohács: A History of Ottoman-Hungarian Warfare, 1389-1526. Leiden; Boston: Brill, 2018.

Parapat, Janez. "Doneski k zgodovini kranjskih mest. II: Kočevje”. Letopis Matice slovenske 5 (1874): 73-101.

Pleše, Tajana; Sekulić, Petar. "Jelengrad i Košutgrad - Dva moslavačka stara grada / Jelengrad and Košutgrad - Two Burgs in Moslavina”. Prilozi Instituta za arheologiju u Zagrebu 30 (2013): 69-92. 
Rady, Martyn. “The Government of Medieval Buda”. In: Medieval Buda in Context, ed. Balázs Nagy, Martin Rady, Katalin Szende, and András Vadas, 303-321. Leiden: Brill, 2016.

Raukar, Tomislav. "Grofovi Celjski i hrvatsko kasno srednjovjekovlje”. Historijski zbornik 36 (1983): 113-140.

Regesta Imperii Online. Last accessed on April 25, 2020. http:/opac.regesta-imperii.de/ lang_de/.

Repertorium Germanicum Online. Last accessed on April 25, 2020. http://www.romana-repertoria.net/993.html.

Stipišić, Jakov; Šamšalović, Miljen. "Isprave u Arhivu Jugoslavenske akademije (Nastavak - do smrti kralja Matije Korvina)". Zbornik Historijskog instituta Jugoslavenske akademije 3 (1960): 563-643.

Szende, Katalin. "Integration through Language: The Multilingual Character of Late Medieval Hungarian Towns". In: Segregation - Integration - Assimilation: Religious and Ethnic Groups in the Medieval Towns of Central and Eastern Europe, ed. Derek Keene, Balázs Nagy, and Katalin Szende, 205-233. Farnham; Ashgate, 2009.

Škreblin, Bruno. “Nijemci na Gradecu sredinom i u drugoj polovici 15. st.”. Godišnjak Njemačke zajednice / DG Jahrbuch 17 (2010): 33-54.

Škreblin, Bruno. "Ethnic Groups in Zagreb’s Gradec in the Late Middle Ages”. Review of Croatian History 9 (2013), No. 1: 25-59.

Thallóczy, Lajos; Barabás, Samu, ed. Codex diplomaticus comitum de Blagay. Budapest: A Magyar Tudományos Akadémia Könyvkiadó-Hivatala, 1897.

Thuróczy, János. Chronicle of the Hungarians, trans. and ed. Frank Mantello and Pál Engel. Bloomington, IN: Indiana University Research Institute for Inner Asian Studies, 1991.

Tkalčić, Ivan Krstitelj, ed. Monumenta historica liberae regiae civitatis Zagrabiae, vol. 2. Zagreb: Karl Albrecht, 1894.

Tkalčić, Ivan Krstitelj, ed. Monumenta historica liberae regiae civitatis Zagrabiae, vol. 7. Zagreb: Karl Albrecht, 1902.

Tkalčić, Ivan Krstitelj, ed. Monumenta historica liberae regiae civitatis Zagrabiae, vol. 10. Zagreb: Karl Albrecht, 1904.

Uhlirz, Karl, ed. Quellen zur Geschichte der Stadt Wien, part II: Regesten aus dem Archive der Stadt Wien, vol. 2: Verzeichnis der Originalurkunden der Städtischen Archives 14121457. Vienna: Verlag und Eigenthum des Alterthums-Vereines zu Wien, 1900.

Urbánek, Rudolf. Konec Ladislava Pohrobka. Prague: Česká akademie věd a umění, 1924. Widmer, Georg. Urkundliche Beiträge zur Geschichte des Gottscheerländchens (14061627). Vienna: Verein der Deutschen aus Gottschee in Wien, 1931. 
Tomislav Matić

\section{Izgon Nijemaca iz Zagrebačkog kaptola 1458. godine}

\section{Sažetak}

Ovaj rad bavi se slučajem izgona sedmorice kanonika iz Zagrebačkog kaptola 1458 godine. U žalbi koju su iznijeli pred papom, rečeni kanonici ustvrdili su da je jedini razlog za njihovo protjerivanje bilo to što su Nijemci. Istraživanjem slučaja ustanovljeno je da je glavni pokretač tih događaja bio biskup Demetrije Čupor, koji se tek nedugo prije toga, nakon petnaestak godina pravne i oružane borbe, domogao kontrole nad Zagrebačkom biskupijom. U radu se nastoji utvrditi razloge za Demetrijevo neprijateljsko postupanje prema njemačkim kanonicima, pri čemu je ustanovljeno da nije postojala čvrsta zakonska podloga za njihov izgon iako su on i njegovi pobornici tvrdili da jest. Čini se da je u to vrijeme zaista vladala određena antinjemačka klima u Ugarskom Kraljevstvu, ali se vjerojatnijim čini da je Demetrije ciljao točno određenu skupinu kanonika te da izlučni kriterij nije bio to što su bili Nijemci. Iako je neosporno da je nagrađivanje vlastitih pobornika nadarbinama izgnanih kanonika bilo jedan od njegovih motiva, čini se da su se na meti progona našli kanonici koji su podržavali grofove Celjske ili pak cara Fridrika III. Habsburga, dakle protivnike Demetrija i njegove strane u ugarskim dinastičkim sukobima. U prilog tome govori i to što se većina izgnanih kanonika relativno brzo vratila u Kaptol, ali oni koji su bili čvršće vezani uz cara nisu, nego su svoje karijere nastavili u Svetom Rimskom Carstvu.

Ključne riječi: srednji vijek, crkvena povijest, Nijemci, Zagrebačka biskupija, etnička netolerancija

\footnotetext{
* Tomislav Matić, Hrvatsko katoličko sveučilište, Ilica 242, 1000 Zagreb, Republika Hrvatska,
} E-mail adresa: tomislav.matic@unicath.hr 